\title{
A RAT ON THE PLATE: THE LAST SUPPER WINDOW IN SAINT MARY'S CHURCH, WARWICK
}

\section{Olivier BAUER}

Dernière version «auteur» de l'article : Bauer, O. (2012, Winter). A Rat on the Plate: Last Supper's Window in Saint-Mary's Church, Warwick. Gastronomica. The Journal of Food and Culture, 12 (4), 62- 67.

On August 28, 2010, I got an e-mail from Rene Greville. Having heard about my research into the food that Leonardo da Vinci represented in his famous Il Cenacolo, he wanted to draw my attention to the windows in the vestry of St. Mary's Church, Warwick (UK), his 'family church':

'One window shows The Last Supper. It is believed to have been in the Chapter House where Fulke Greville’s famous “Rosicrucian” monument (Professor James Stevens-Curl) was built in 1618. The picture is very strange. The oddest thing is that the plate in front of Jesus shows a large rat running across it."

Greville asked for my help, 'to discover Fulke Greville's exact intention when he commissioned the rat in the Last Supper window for his Rosicrucian "Temple." 3 ' He sent me a high-definition picture of the window.

\footnotetext{
${ }^{1}$ S.-J. Desjardins, Leonardo Da Vinci's The Last Supper' Reveals More Secrets (30 March 2010), accessed 6 May 2011, http://www.eurekalert.org/pub releases/2010-03/uom-ldv033010.php

2 R. Greville, personal e-mail, 12 December 2010.

3 Ibid.
}

Olivier Bauer - olivier.bauer@unil.ch

Institut lémanique de théologie pratique - Faculté de théologie et de sciences des religions

Université de Lausanne (Suisse) 


\section{Unil}

UNIL | Université de Lausanne

Institut lémanique de théologie pratique

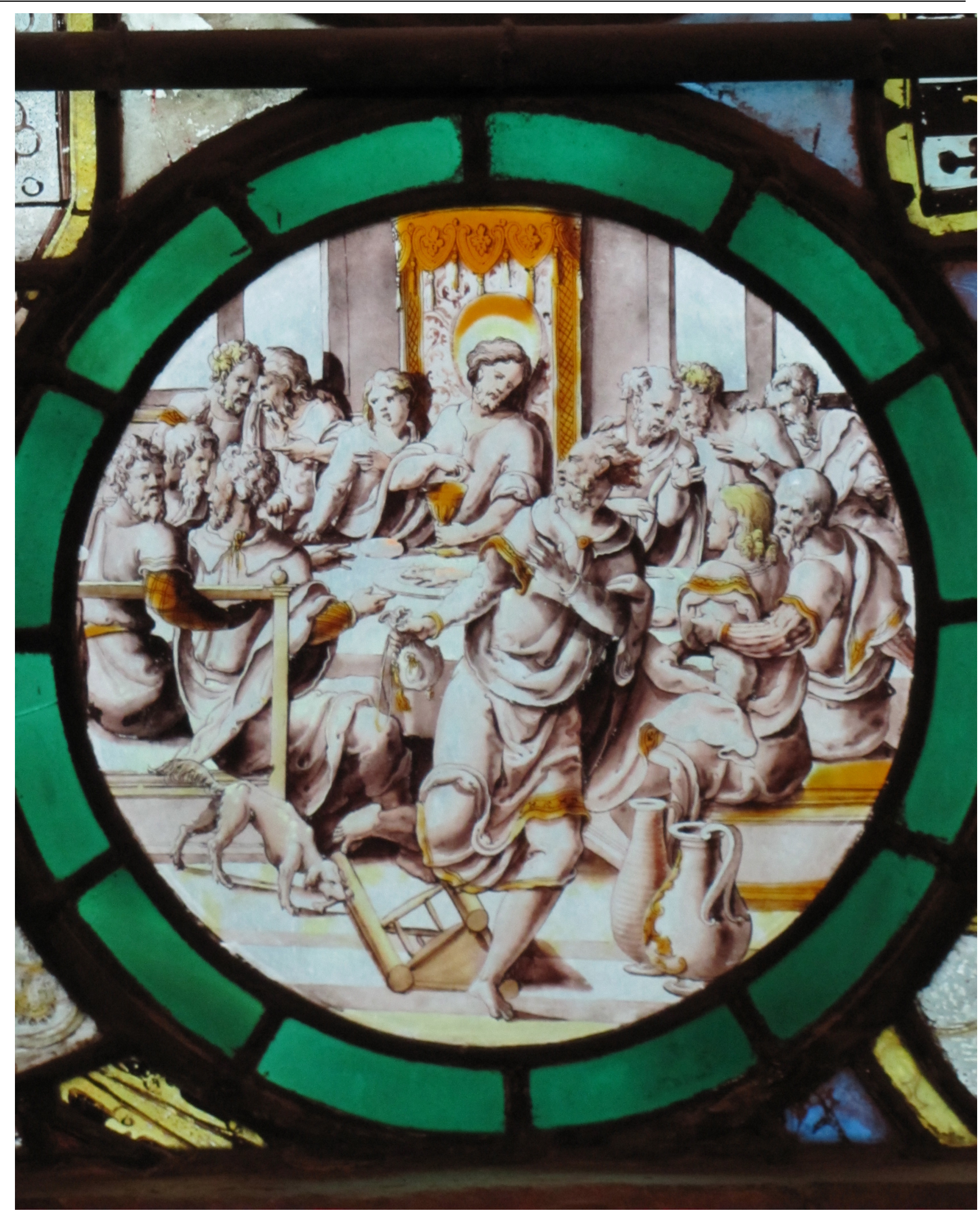

Figure 1: Last Supper's window in St. Mary's, Warwick 
Intrigued by his request, I began working (from my office in Montreal - I never went to Warwick ${ }^{4}$ ) to understand why there should be a rat running across the plate in front of Jesus. First, I needed to learn more about the window. The Collegiate Church of St. Mary, Warwick's website, ${ }^{5}$ and some documents Rene Greville sent me, provided context:

'St. Mary's was founded in 1123 [but] the Chancel, Vestry and Chapter House were rebuilt in the Fourteenth Century by Thomas Beauchamp, and this section of the building represents one of the highest peaks of English Gothic architecture. The tomb of Thomas Beauchamp stands in front of the high altar; the tiny figures around its base give a fine depiction of Fourteenth Century English fashion. Fulke Greville's enigmatic monument takes up most of the Chapter House. ${ }^{6}$

Furthermore, the 'enigmatic monument' itself, also known as 'the temple,' 'was designed in 1618 by Sir Fulke Greville and was constructed, before 1621, for the modern equivalent of $£^{3} 300,000$, closely following 'designs by [Fulke Greville's] two close associates, Giordano Bruno and Robert Fludd, both inventors of Memory Theatres ${ }^{7}$. It 'filled [the Chapter House] almost to the ceiling'. It is 'quite plain, with a large black marble sarcophagus and pillars. It is unusually aligned North/South. ${ }^{8}$ In the Vestry, there are 14 roundels and one square window and, more to the point of my investigations:

'There is disagreement over the date of the panels which have been dated (individually) between 1325 and the early 17th century. The Last Supper has been dated between c. 1550 and early 17 th century."

Thus oriented, I began trying to understand why an artist decided to include a rat on a plate (in fact despite what Greville wrote, the rat is not 'running across' the plate, but rather it is dead and lying in the plate) in a depiction of the Last Supper ${ }^{10}$. I explored four possible answers through four questions, each following from the last: 1) Is the dead animal in the central plate really a rat? 2) Is a rat uncommon in a Last Supper representation? 3) Is rat a common food? And, finally, 4) What does the rat stand for?

${ }^{4}$ In October 2012, I finally went to Warwick, visited the St. Mary's Church and saw Greville’s Last Supper.

${ }^{5}$ Collegiate Church of St Mary, Warwick. Retrieved January 31, 2011, from http://www.saintmaryschurch.co.uk/

6 Ibid.

${ }^{7}$ Greville, personal e-mail, December 2010.

8 'Fulke Greville's Mysterious "Monument without a Tombe" (2007), accessed 31 January 2011, http://www.masterofshakespeare.com/monument.htm.

${ }^{9}$ R. Greville, personal correspondence, 5 February 2011.

${ }^{10}$ Despite what Greville wrote, the rat is not actually 'running across' the plate; rather, it is dead and lying on the plate. However, for the purposes of this essay I retain the trope of the running rat. 


\section{Is the Dead Animal in the Central Plate Really a Rat?}

I have to confess that I began this research with some bias. When I first looked at the window, I had already been told there was a rat on the plate in front of Jesus, and I immediately identified it. But when I looked more carefully, I was not so sure that this animal on the plate really was a rat. I still remain doubtful. It is hard to be quite sure about it: the animal is just a sketch, a rather small and simple sketch, and its bottom part is missing. If it looks like a rat, it could also be a rabbit or some other rodent. And I am looking at it with my twenty-first-century eyes - maybe the rat on the plate appears exactly the way a rat was drawn in the sixteenth century. Maybe not! So, I found two significant examples of drawings from the same period that depicted rats.

The first was drawn by the Swiss naturalist Konrad Gesner in the mid-sixteenth century ${ }^{11}$.

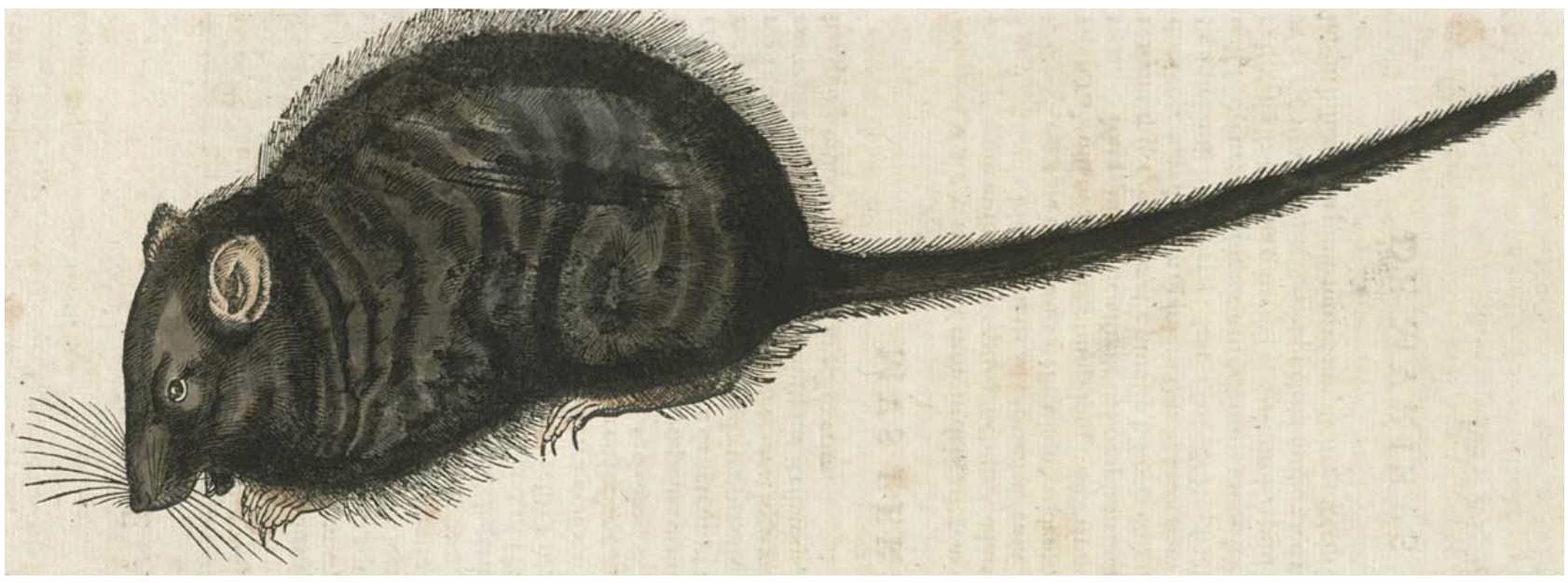

Figure 2: A rat drawn by Konrad von Gesner (1551-1558)

For sure, Gesner's rat looks quite different than the animal in St. Mary's window. And it looks much more like the animal I call a rat: it has a rat's muzzle and mustache, a rat's eyes, ears, claws, fur, and tail, and a rat's color. Here is a rat, beyond any reasonable doubt. One objection you could raise is that this it is quite a different type of picture. Gesner's rat comes from an illustration in an academic book, while the St. Mary's Last Supper is a work of religious art. You would be perfectly right. I would even add that using the stained-glass technique makes exact representation much more difficult. Perhaps comparing St. Mary's rat and Gesner's rat is not the best way to decide if there really is a rat on the plate in front of Jesus.

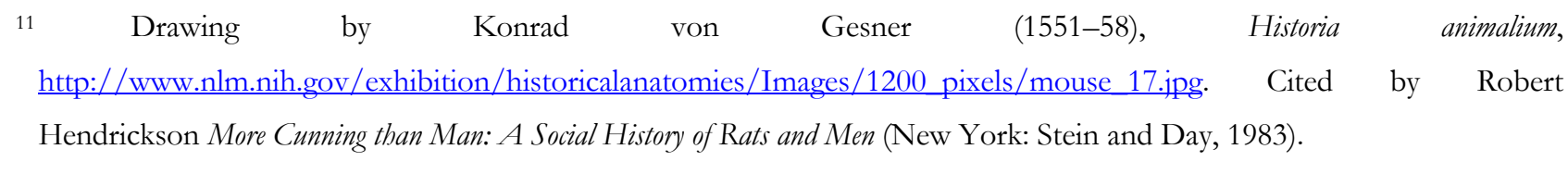


So, let us consider another drawing, this one from an anonymous drawer in the Fifteenth Century:

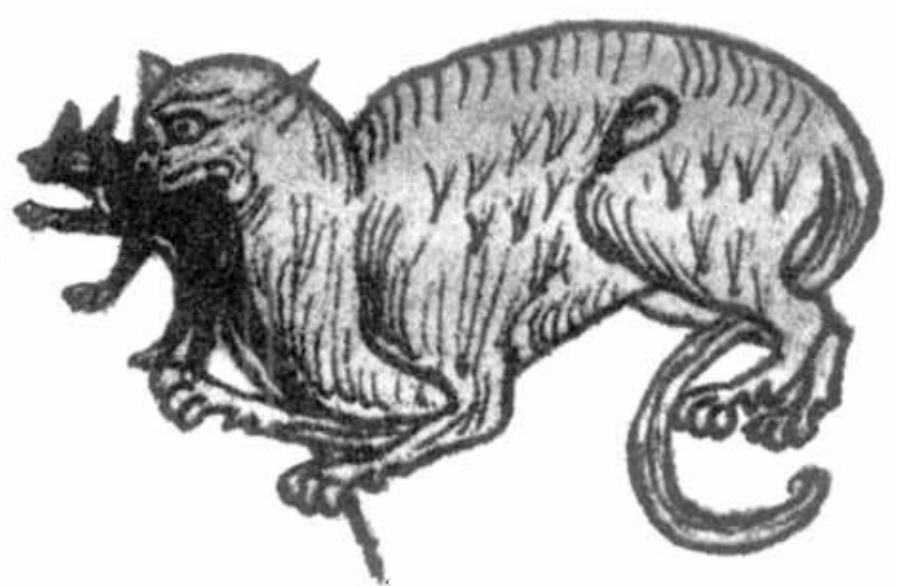

Figure 3: 'A rat in the late Middle Age' after Beryl Rowland

The first surprise for me was that the rat depicted here is not the little black animal, but the big gray one! S. Anthony Barnett, in whose book I found this drawing, explains that 'In Europe in the Middle Ages rats were sometimes held to be supernatural creatures and portents of evil. [Here, a] giant rat seizes a cat. $^{12}$

If Gesner's rat was realistic, this rat is less so: its muzzle is short, its head is round, its ears are pointy, its legs are rather long, and it does not have any mustache. Only the color and the tail are particularly ratlike. For me, for my modern-Western-scholar eyes, this big gray animal does not look like a rat eating a cat, but like a giant cat eating a small dog. But my mind does not matter here. The fact is that, in the late Middle Ages (not very long before the St. Mary's window was created), rats were sometimes represented like this. And if Gesner's rat was an academic way to represent rats, this late Middle Ages rat was a popular way to see and draw them.

Coming back to the St. Mary's rat, I can conclude that around Fulke Greville's time (the beginning of the Seventeenth Century), there existed different ways to represent rats, and that pictures of rats did not need to realistically depict all the characteristics of the actual animal to be recognized as rats. Therefore, I concede that Saint Mary's window shares some similarities with those two drawings: in common with the first drawing are the long muzzle, the round ears, and the small legs (of course, the identification would be easier if we could see a long tail); the second drawing shares with the window a freedom of

12 'A rat in the late Middle Ages,' from Beryl Rowland, Animals with Human Faces: A Guide to Animal Symbolism (Knoxville: University of Tennessee Press, 1973). The image is reproduced in S. Anthony Barnett, The Story of Rats: Their Impact on Us, and Our Impact on Them (Crows Nest, NSW, Australia: Allen \& Unwin, 2001), 7. 
line. Despite the simple, sketched quality of the shape on St Mary's window, I can admit that there could really be a rat running across the plate.

\section{Is a Rat Uncommon in a Last Supper Representation?}

If I concede that the dead animal in the central plate on Saint Mary's window is a rat, I cannot draw conclusions about its meaning without first ascertaining if rats as food are an uncommon feature of Last Supper representations during the sixteenth century. In some other Last Supper paintings of the same period, we can see different food items on Jesus's table. Some are easy to identify (bread loaves, fishes, oranges, salt, etc.), others quite difficult to recognize. Sometimes, the food in the central plate is clearly an animal, and it sometimes looks as awkward as the St. Mary's rat. Let us look at an example, by the Spanish painter Alonso Vázquez. ${ }^{13}$

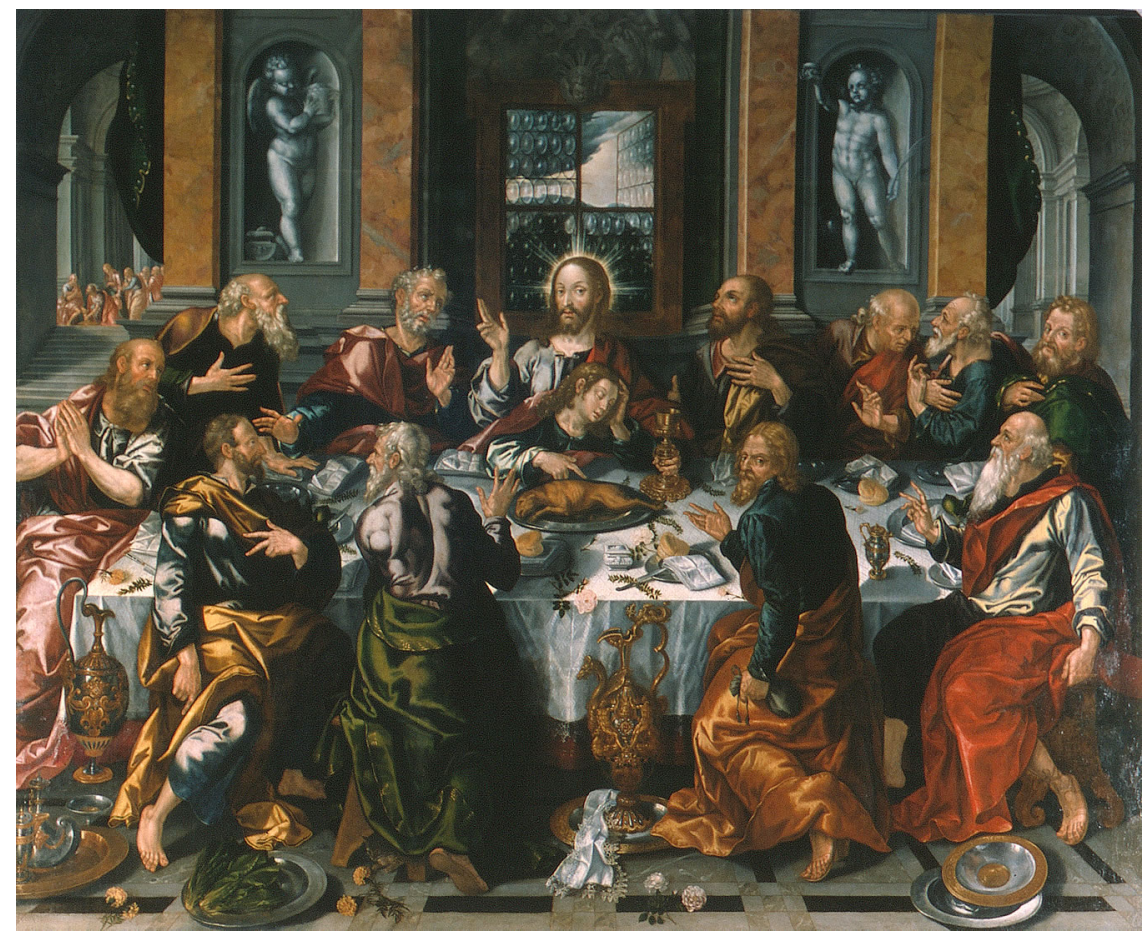

Figure 4: Sagrada Cena by Alonso Vàzquez.(1588-1603)

In Vázquez's painting the food on the plate in front of Jesus is beyond any doubt a whole, skinned animal. But what is it? Judging by size, it could be a dog, a cat ... or a big rat, though the general shape, the muzzle, the ears and what looks like hooves put me in mind of a lamb ${ }^{14}$. And of course, finding a small

13 Alonso Vázquez, Sagrada Cena (1588-1603). Museo de Bellas Artes de Sevilla: http://nl.wikipedia.org/wiki/Bestand:Alonso vázquez sagrada cena.jpg.

14 We are not done with the Last Supper's surprising food. In the Cathedral 
lamb on a Last Supper painting makes sense, even if we do not know whether Jesus ate lamb for his Last Supper. Lamb or lamb bone is a food required for celebrating the Seder meal ${ }^{15}$, the 'Passover' that three Gospels present as the last meal Jesus wanted to share with his disciples (Luke 22: 7; Matthew 26: 17; Mark 14: 12). It could have been on Jesus's table. Also, the Gospel according to John spoke of Jesus as the 'Lamb of God' (John 1: 29 and 36). The richness of the symbolism makes it plausible that Vázquez painted a dead lamb in the center plate, as a prefiguration of the Lamb who will be sacrificed or executed on Good Friday.

The four mentions of Jesus's Last Supper in the New Testament (the Gospels according to Matthew 26:20 - 30, Mark 14:12 - 31, and Luke 22:1 - 23; Paul's Epistle to the Corinthians 11:23 - 26) disagree on many elements. But they all agree that to celebrate his Last Supper, Jesus used some bread and a cup. The three Gospels agree that the cup was full of the fruit of the vine. No other food is mentioned, neither lamb nor fishes nor oranges nor salt. Therefore, if various artists have chosen to put some other food on the Last Supper table, they have done so for symbolic reasons.

\section{Is Rat a Common Food?}

Before we begin searching for the symbolism of the rat, we could find a very basic explanation for its presence: rats could have simply been a common food in Fulke Greville's time. I remind those who might be disgusted by such an idea that rats really are edible - that they really have been, and are, a food, in various contexts and times, and under various conditions, notably on board ships at sea:

'In sailing ships in which rats were as familiar as bed bugs, pursuing them no doubt relieved boredom; but they were also eaten, which suggests an interesting possibility. Famously, sailors on long voyages were liable to scurvy, owing - we now know - to lack of vitamin C (ascorbic acid). The rats, like the crew, lived largely on salt pork, dried peas and ship's

of Santo Domingo in Peru, there is a Last Supper painting by Marcos Zapata (1753) with what looks like a guinea pig in the central plate. 'In Zapata's blending of Andean culinary tradition with an allegiance to a religion brought by the conquistadors, the Last Supper exemplifies the sentiment found in most Cuzco paintings. Guinea pig may be a surprising departure from traditional renderings of the Last Supper, but this fare aptly reconfigures Christian symbolism within Andean culture and tradition.' Christina Zendt, 'Marco Zapata's Last Supper. A Feast of European Religion and Andean Culture,' Gastronomica 10, no. 4 (2010): 11. Let's come back to rats: in the Hollywood remake of the French movie Le dîner de cons, Steve Carrell reenacts da Vinci's Cenacolo with stuffed rats! J. Roach, writer, Dinner for Schmucks (USA: Paramount Pictures, 2010).

${ }^{15}$ Cf. N. Goldberg, Passover Haggadah: A New English Translation and Instruction for the Seder, $5^{\text {th }}$ ed. (Hoboken, NJ: Ktav Publishing House, 1993.) 
biscuit; but they were better off than the sailors for, like most mammals, they can synthesize vitamin from other food substances. Perhaps, on long voyages, raw or lightly cooked rats were a useful source of vitamin $\mathrm{C}$ and so helped to prevent scurvy. A survivor of one of the appalling voyages in the South seas of Fernando Magellan (? 1480-1521) describes living on powdered, wormy biscuits stinking of rat urine; and he complains that he and his companions could not get enough rat to eat. ${ }^{, 16}$

Though rats probably were used as a food in Greville's time, it seems to have been only under special circumstances or to indulge a particular taste. One check on rats being a common part of a Western diet was that, though Christianity repealed most of the Jewish dietary laws, Christians tended to retain the Jewish ban on eating any rodent:

'The strongest ancient restriction regarding rats is found in the Old Testament, where in Leviticus, chapter 11, and Deuteronomy, chapter 14, the basis for many Jewish dietary practices, the consumption of any "creeping animals such as the mouse", is forbidden. Since there is but one Hebrew word for rat and mouse this reference could be to the fat dormouse, the fat sand rat, or the jerboa, all of which were eaten at the time in the Middle East. In any case, according to Biblical dietary laws, anyone who even touches a "swarming thing that crawls upon the earth" is "unclean until evening" and any clean thing that falls upon such a swarming thing "must be put into water, and it shall be unclean until the evening". When Christianity was born and broke with Hebrew dietary prescriptions, for various reasons, the prejudice against the rat as food was, of course, a taboo never abandoned by most converts. ${ }^{17}$

I conclude that it would be highly improbable that the rat runs across the plate because Fulke Greville or the unknown artist liked to eat rats.

\footnotetext{
${ }^{16}$ Barnett, Story of Rats, 10-11. If you think that rat could be a food only in a kind of emergency, think again: 'Strictly for gourmets. A reader who wishes to eat rats can resort to a standard work, Guide to Good Food and Wines by André Simon [1960]. For both Norways and black rats, he recommends a stuffing made from breadcrumbs, the minced liver and heart of the rat, and sweet herbs, pepper, and salt. Roast for a few minutes in a hot oven. Young rats, he adds, may be made into pies. Larousse Gastronomique has an alternative, derived from the practice of coopers in the wine stores of the Gironde. After they had been skinned and cleaned, the rats were seasoned with oil and plenty of shallots and grilled over an open fire. Both authorities emphasize the excellence of rat flesh; but, I am sorry, neither gives the number of rats needed per person.'

${ }^{17}$ Hendrickson, More Cunning than Man, 232.
} 


\section{What Does the Rat Stand For?}

If the animal on the plate is a rat, if it is uncommon in a depiction of the Last Supper, and if it is a nonJewish and non-Christian food, then this rat on the plate becomes quite interesting. It might be understood as a sign the unknown artist used to convey a message. But what did he want to communicate? That is the question. To find the answer, we need to discover what rats did mean in a Christian context during Fulke Greville's times.

Indeed, rats had quite a negative symbolic value in Christianity:

'During the Middle Ages rats were believed to be creatures of evil, the lapdogs of the devil, even though they were not associated with the deadly plague that they carried. Both the devil and witches were said to change into the forms of rats and mice so that they could sneak about and pry into human affairs without being noticed. ${ }^{18}$

Churches used the rat precisely as a symbol of the devil or of evil. In a paper written in $1848^{19}$, French archivist and paleographer Alphonse Duchalais identified three churches where depictions of rats were part of the decoration: the Cathedral of Le Mans, Saint-Germain-l'Auxerrois in Paris, and the old Collegial of Champeaux en Brie ${ }^{20}$. Those rats were 'the emblem of a destructive agent', that is, 'the vices which lead into sin and eternal damnation ${ }^{21}$.

In Christianity, rats seem to fulfill another symbolic function. In the Lutheran Church of St. Marien zu Lübeck in Germany, the altar has a Lord's Supper representation carved in stone. At the bottom of the table, on the right corner of the Lord's Supper tableau, there is a rat (or a mouse; at this time, they

18 Ibid., 142-143.

19 A. Duchalais, Le rat, employé comme symbole dans la sculpture du Moyen Âge. Bibliothèque de l'école des chartes (1848), 9, 229243.

${ }^{20}$ Ibid., 234. Duchalais indicates that rat is 'une représentation qui semble n'avoir été guère usitée qu'à la fin du quinzième siècle et dans le courant du seizième.' In a footnote, he mentioned two other churches in France: the Church of Gassicourt, near Mantes and Saint-Siffrein of Carpentras.

21 'Ce qu'il nous est possible seulement de tirer de tout ceci, c'est que ces animaux sont l'emblème d'un agent destructeur, d'un mal quelconque, que chacun doit fuir. Or, quelle chose est plus à fuir que les vices qui mènent au péché et à la damnation éternelle ? Cette dernière réflexion et l'élasticité des symboles du Moyen Âge, eu égard surtout à ceux qu'on tire de la représentation des animaux, ainsi que de la position qu'ils occupent dans les grandes scènes historiées, nous ont engagé à voir ici dans les rats l'emblème des vices.' Ibid., 236. Sometimes, this 'random evil' was embodied in very concrete figures. For example, in 1495, in a Protestant polemical context, "Martin Luther called the pope "the king of rats", terming Catholic cardinals a "rabble of rats" and monasteries "rat's nests." Hendrickson, More Cunning than Man, 141-142. (Luther's Werke, vi, 97.) 
were not strictly differentiated). The rat and the stone around it appear gray, a darker color than the stone, and polished smooth - used. This is not by any chance, but because people used to (and probably still do) touch the rat for luck:

'In line with the Last Supper relief is Lübeck's emblem: once significant in Lübecken legend,

kleine Maus (small mouse), which gnaws at rose trees. Contact with it brings good luck. ${ }^{22}$

This rat in Lübeck fulfills another theological function. Its position on the floor, below the Last Supper table, means it is probably a Lutheran answer to a classical theological controversy about the Eucharist: if a mouse eats a crumb of the host that has fallen down during the Eucharist, would this mouse have communicated? That is, would it have eaten Christ's body? In his criticism of the Church and its theology, Jean Hus (? 1371-1415), a Czech precursor of the Protestant Reformation, gave a clear negative answer. What the rat eats can only be the species (i.e., the bread or host). To be effective, i.e., for the bread to become Christ's body, the sacrament requires the intention of the person who communicates:

'The mouse (if it should collect the sacrament and eat it) can move only the species (manifestation) of the bread, because it takes the sacrament not sacramentally, not as a sacrament. ${ }^{23}$

In this Lutheran Church, then, according to Hus's theology, rats would not represent the devil or evil anymore. They still remain suspicious, but they now represent a person who does not properly understand how the Eucharist, or the Lord's Supper, works. From a Protestant perspective, any Catholic could be a figured as a rat, since Protestants accused them of believing that a piece of the host could magically affect any person (or any animal) who ate it.

It is clear that rats fulfill various theological functions in Christianity. And the rat in the window at St. Mary's should not be any exception. In fact, I am deeply convinced that it runs across the plate for some theological purpose.

'Before concluding, I want to examine one more possibility around the rat's symbolic value.

22 Marienkirche (Lübeck) (20 May 2011), $\quad$ accessed $24 \quad$ May 2011 , https://en.wikipedia.org/wiki/St. Mary\%27s Church, Lu\%CC\%88beck. For more information, see the official site of the Lübecks Evangelische-lutherische Kirche: 'Die Kirchenmaus Rosemarie,' accessed 24 August 2011, http://www.st-marienluebeck.de/die-kirchenmaus-rosemarie.html.

23 'Die Maus (wenn es sich treffen sollte, daß sie das Sakrament nähme und fräße) kann nur die Spezies (Erscheinungsform) des Brotes bewegen, den sie nimmt das Sakrament nicht sakramental, nicht als Sakrament.' J. Hus, Glaubensstimme - Vom Glauben unserer Vorfahren (11 July 2010), accessed 30 May 2011, www.glaubensstimme.de/doku.php. 
So far, we've dealt with the symbolic value of the rat as a beast. Perhaps it is not the animal that matters, but its name: "rat" as a word". This line of inquiry could be fruitful; according to the Oxford English Dictionary, apart from the classical definition ("any rodent of the genus Rattus and related genera of the family Muridae, resembling a large mouse, often with a naked or sparsely haired taill" ${ }^{25}$ ), by the sixteenth-century rat also meant "A dishonest, contemptible, or worthless person; spec. a man who is deceitful or disloyal in a romantic relationship." "26

If we take the rat on the plate for food, it can only be odd and meaningless. We are tolerably sure that Jesus did not eat rat for his Last Supper, and quite sure that he did not order his disciples to eat rat 'in memory of him', and that no church includes rat in its Eucharistic offering. But when we take the rat as a symbol, it becomes powerfully meaningful, with significance within a Christian theological framework.

May I ask you who, on St. Mary's window, is the 'portent of evil'? Who is 'the lapdog of the devil'? Who is the 'destructive agent' whose vices 'lead into sin and eternal damnation'? Who 'does not understand properly how Lord's Supper works'? Who is 'a dishonest, contemptible person,' 'a man who is deceitful or disloyal?'

There are two figures who fit with those elements: the rat, of course, but also the man with a purse, running away from the Lord's table, in such a hurry that he has overturned his chair. As I can see, there are two 'rats' on the St. Mary's window. One runs across the plate, the other runs from the table. One is the animal, the other is Judas, the disciple who betrayed Jesus:

'Then one of the Twelve - the one called Judas Iscariot - went to the chief priests and asked,'What are you willing to give me if I deliver him over to you? 'So, they counted out for him thirty pieces of silver. From then on Judas watched for an opportunity to hand him

\footnotetext{
${ }^{24}$ In our research on da Vinci's Cenacolo, we already concluded that Leonardo painted eels in his masterpiece for the sake of their name. In the fifteenth century, 'anguilla' (the Italian word for eel) evoked traitors, treason and deception: O. Bauer \& N. Labonté (2015). Le Cenacolo de Leonardo da Vinci. Un trompe-la-bouche. Théologiques 23, no. 4 (2015) : 39-65. We know that in alchemy likes to play on words. For example, in a French context a 'souris' (a mouse) evokes a 'sourire' (a smile). Burensteinas, P. (2011, 9 mars). 'Herméneutique et alchimie.' Paper presented at the Conférence midi du Centre d'études des religions de l'Université de Montréal, Université de Montréal.

25 'Rat,' 3rd ed. (Oxford: Oxford University Press, 2010): 2.

26 'Rat' (2010): 5. Shakespeare uses 'rat' in this sense in Richard III V. VI. Sixty-one: 'These famisht beggers. Who. For want of means poore rats had hangd themselues.'
} 
over. $^{27}$

Clearly, the rat on the plate works as a sign or a signal. It draws the viewer's attention to the other rat in the scene, the traitor, either Judas (according to Matthew 26:21 - 25 and parallels), or Satan (who, according to John 1:27 pm, would have been at the table after having entered into Judas during the supper), who is in the end the only one who matters. The rat's symbolic value becomes even more evident when it is contrasted with the only other animal in the window, the dog, which is the rat's exact opposite: a symbol of trust and fidelity ${ }^{28}$.

For the rat running across the central plate has nothing to do with him; neither it is a primarily aesthetic choice. Not at all, if you consider that, in the Gospel according to Matthew, the traitor is identified as the one who dips his hand into the same plate at the same time as Jesus: 'Jesus replied, "The one who has dipped his hand into the bowl with me will betray me"29, St. Mary's window seems to say that it is the one who has touched the rat with Jesus who will betray him. So, the rat on the plate fulfills two theological purposes: it signifies that there is a traitor at the table, and it reveals who he is. Not bad for such a hated animal!

\footnotetext{
27 Matthew 26:14-16.

${ }^{28}$ Of course, the dog also refers to another Biblical story wherein a woman reminds Jesus: 'Even the dogs under the table eat the children's crumbs,' Mark 7:27. Note that the dog on St. Mary's window is eating a bone. Could it be the lamb's bone Jews have to eat for the Seder meal? If so, the dog would be one of the most faithful figures in the window.

${ }^{29}$ Matthew 26:20-25.
} 